\title{
Trees for development? Articulating the ambiguities of power, authority and legitimacy in governing Ghana's mineral rich forests
}

Article

Accepted Version

Hirons, M. (2015) Trees for development? Articulating the ambiguities of power, authority and legitimacy in governing Ghana's mineral rich forests. The Extractive Industries and Society, 2 (3). pp. 491-499. ISSN 2214-790X doi: https://doi.org/10.1016/j.exis.2015.05.001 Available at https://centaur.reading.ac.uk/44176/

It is advisable to refer to the publisher's version if you intend to cite from the work. See Guidance on citing.

To link to this article DOI: http://dx.doi.org/10.1016/j.exis.2015.05.001

Publisher: Elsevier

All outputs in CentAUR are protected by Intellectual Property Rights law, including copyright law. Copyright and IPR is retained by the creators or other copyright holders. Terms and conditions for use of this material are defined in the End User Agreement. 


\section{CentAUR}

Central Archive at the University of Reading

Reading's research outputs online 


\title{
Trees for development? Articulating the ambiguities of power, authority and legitimacy in governing Ghana's mineral rich forests
}

\author{
Mark Hirons \\ University of Oxford - School of Geography and the Environment \\ University of Reading - School of Agriculture, Policy and Development \\ Email: m.a.hirons@reading.ac.uk
}

\begin{abstract}
The growth of mining activities in Africa in the last decade has coincided with increased attention on the fate of the continent's forests, specifically in the contexts of livelihoods and climate change. Although mining has serious environmental impacts, scant attention has been paid to the processes which shape decision-making in contexts where minerals and forests overlap. Focussing on the illustrative case of Ghana, this paper articulates the dynamics of power, authority and legitimacy of private companies, traditional authorities and key state institutions in governing mining activities in forests. The analysis highlights how mining companies and donors promote a neoliberal model of resource management which entrenches their ability to benefit from mineral exploitation and marginalises the role of state institutions and traditional authorities in decision-making. This subsequently erodes state authority and legitimacy and compounds the contested nature of traditional authorities' legitimacy. A more nuanced examination of foundational governance questions concerning the relative role of the state, traditional authorities and private interests is needed.
\end{abstract}

\section{Introduction}

The mineralisation of sub-Saharan African economies, combined with growing concern regarding the consequences of diminishing forest cover on climate and poor forest-dependent communities, is increasingly drawing attention to the interactions between mining and forestry (Cotula, 2012; Edwards et al., 2013). Well-articulated concerns about the efficiency, 
equity and sustainability of mineral exploitation in sub-Saharan Africa are amplified in forest-rich contexts because intact forests provide a multitude of (often under-valued) ecosystem services across a range of scales. Forests also play a critical role in the livelihoods of poor people who often do not benefit from mining activities, but bear the associated social and environmental costs of extraction (Akabzaa, 2000; Dondeyne et al., 2009; Ferguson, 2006; Whitmore, 2006).

Navigation of the environmental and social conflicts and trade-offs ${ }^{1}$ associated with mining in forested landscapes is largely contingent on the governance arrangements which shape decisions over natural resources. However, assessments of the multifarious trends and drivers of natural resource governance in sub-Saharan Africa are criticised for unfolding within sectoral $^{2}$ 'silos', long recognised as a barrier to the formulation of holistic and more nuanced analyses of how resources are governed within their broader landscape (Sayer and Campbell, 2005; Young et al., 2014). As Mwitwa et al. (2012:20) point out, 'a great deal is now known about forest governance in landscapes shaped by internal dynamics within the sector... much less is known, however, about forest governance in the context of extra-sectoral investments'. Sectoral analyses frequently fail to explicitly address the conflicts and trade-offs which underlie much of the scepticism regarding the simultaneous achievement of the environmental and developmental goals of sustainable development. This is epitomized in debates regarding emerging 'win-win' strategies to environmental governance, such as schemes to reduce emissions from deforestation and degradation (REDD) (Gupta, 2012). The inclusion of concerns regarding livelihoods within $\mathrm{REDD}+{ }^{3}$ and the broader shift towards examining 'landscapes' (Sayer et al., 2013) underscores the need for further consideration of forest exploitation and conservation within their wider resource-use contexts.

There is, however, a dearth of detailed empirical analyses which investigate the complex multi-scale interactions that characterise cross-sectoral governance, as well as how these dynamics are shaped by the power, authority and legitimacy of key stakeholder groups (see Mwitwa et al., 2012 and Hirons, 2013 as notable exceptions). Building on analysis presented in Hirons (2013) of mining in Ghana's high forest zone, this paper aims to fill this gap by

\footnotetext{
${ }^{1}$ Trade-offs refer to the balancing of competing objectives from one particular perspective and conflicts refer to situations of competition or disagreement between two or more individuals, groups or sectors (after Grimble and Wellard, 1997).

2 Sectors are defined loosely here as a 'conceptual area' of economically productive activity (Dominguez and Plana, 2002)

${ }^{3}$ REDD+ also includes concerns for biodiversity and carbon stock enhancement.
} 
broadening understanding of key issues associated with resource governance in contexts where minerals and forests overlap spatially.

The following section outlines a power-centric approach to examining cross-sectoral natural resource governance. Section 3 outlines the broad characteristics of mining-forest governance in Ghana. This provides the foundation for exploring the authority and legitimacy of mining companies and miners, traditional authorities and the state. The paper concludes by highlighting the need for politicised understandings of natural resource governance. It furthermore calls for attention to be paid to processes capable of fostering deliberation of the relationship between the state and traditional authorities which are fundamental to shaping the governance of mining in forested areas.

\section{Cross-sectoral natural resource governance: Adopting a plurality of perspectives on power}

The overlapping spatial distribution of forest and mineral resources across sub-Saharan Africa gives rise to a series of conflicts and trade-offs, particularly in the context of widespread pursuit of sustainable development which ostensibly aims to balance economic, social and environmental objectives. Understanding the governance of natural resources essentially, who makes decisions about resources and how (after Cotula and Mayers, 2009) is a key to diagnosing mining-forest conflicts and developing equitable and efficient resource management strategies. Analyses of formal rules and regulations governing natural resource use is only partially illuminating: as Wardell and Lund (2006:1888) explain, 'Underneath the changing waves of policy and the restrictive powers of government agencies, another pattern of actual governance unfolds'. This 'actual governance' is shaped by the dynamics of power, authority and legitimacy among stakeholder groups and key actors. This paper focuses on the power dynamics of a sub-set of these actors, namely the primary government bodies responsible for overseeing mining and forest activities, mining companies and traditional authorities.

There are numerous conceptual approaches to power, legitimacy and authority. Although adopting a plurality of perspectives on power presents a risk of conceptual incoherence, the advantage of a broad understanding is that subsequent analyses shed light on power dynamics in multiple dimensions yielding more comprehensive understandings. Here, Weberian 
notions of power as the probability one actor will be able to carry out their will within a relationship are combined with more poststructural conceptions of the operation power, such as through discourse (Foucault, 1994; Humphreys, 2009). Authority is often viewed as 'legitimate power', and while there are definitional debates, it is generally assumed that perceptions of legitimacy affect the likelihood that someone will obey an authority. Legitimacy, therefore, is a central component of understanding resource governance (Colfer, 2011). Power is contingent on the ability of stakeholders to marshal economic, symbolic, cultural and social capital (after Hellström, 2001). They legitimise their claims over access to, and ownership of, natural resources. This process, as Sikor and Lund (2009) explain, revolves around the historical and cultural legitimising practices of different stakeholders which in turn are bound up with precedent, territoriality ${ }^{4}$ and violence.

Adopting a broad view of power draws attention to the importance of structure and agency in governance debates. This sociological schism refers to questions regarding the importance of agency, the process of individual and corporate actors playing an independent causal role in history and making their own free choices (McLaughlin and Dietz, 2008; Brown and Westaway, 2011) relative to structures, the 'sets of mutually sustaining schemas (patterns of thoughts and behaviours) and resources that empower and constrain social action and that tend to be reproduced by that social action' (Sewell, 1992:19). Giddens (1984) argues that neither agents nor structures are omnipotent, and that there exists a 'duality of structure'. But as the analysis that follows demonstrates, understanding the interplay between structure and agency helps to shed light on the multifaceted nature of power dynamics which influence the actual decisions which individuals and communities make and their perceived capacity to influence resource use patterns. The analysis draws on research conducted in the country capital of Accra and three localities: 1) Kibi in the Eastern Region; 2) Obuasi in the Ashanti Region; and 3) Bibiani in the Western Region. In total, 87 semi-structured interviews with purposively sampled key stakeholders, including mining company officials $(n=5)$, small-scale miners $(n=36)$, farmers and chainsaw operators $(n=10)$, national and local government officials $(n=24)$, traditional authorities $(n=5)$ and representatives from non-governmental organisations ( $\mathrm{n}=7)$, were conducted between April 2011 and July 2012. The analysis draws on these qualitative data, as well as field observations, field notes and documentary analysis.

\footnotetext{
${ }^{4}$ The classification and ordering of spatial entities and social groups, often through registration or formalisation.
} 
The next section of the paper examines the case of prospective bauxite mining and smallscale mining in forest reserves to demonstrate the interplay of structure and agency across scales and sectors. This provides the context for examining the power of three primary stakeholder groups in Section 4.

\section{Governing the mining-forest nexus in Ghana: Scale, structure and agency}

In Ghana, reports that environmental degradation is costing the country an equivalent of 1 per cent of its annual gross domestic product (GDP) growth (World Bank, 2006) have helped to articulate concern regarding, inter alia, the impact of large- and small-scale mining on the country's increasingly threatened forests (Hilson and Nyame, 2006; Hirons et al., 2014). These costs are weighed against the significant economic benefits accruing from mining. Formal mining generates approximately 40 per cent of gross foreign exchange in Ghana and accounts for $\sim 6$ per cent of its GDP (Republic of Ghana, 2005). Furthermore, the artisanal and small-scale mining ${ }^{5}$ (ASM) sector, which accounts for approximately 20 per cent of total gold production, provides a valuable livelihood for more than 1 million individuals, the majority of whom are unlicensed. A fundamental distinction exists in Ghana between land and minerals: the former is vested in stools or skins ${ }^{6}$ and the latter, 'in their natural state', are vested in the president on behalf of, and in trust for, the people (Chapter 21, 257(6) of the Constitution). As a result, both traditional authorities and state institutions are of central importance to the governance of natural resources. Three primary government agencies managing the intersection between mining and forestry in Ghana are the Minerals Commission, the Forestry Commission and the Environmental Protection Agency (EPA) (Hirons, 2013). The following analysis traces how these institutions interact at different scales, which lays the foundation for exploring how structure-agency issues influence how these agencies engage with other stakeholders. It is argued that structurally shaped debates regarding trade-offs at a national level are transformed to conflicts at local level, where individual agency shapes outcomes more strongly.

\footnotetext{
${ }^{5}$ There is no definitional agreement on the scales of mining, but in general ASM refers to low-tech, labour intensive extraction of mineral resources

${ }^{6}$ Both stool and skin refer to the 'chiefly office' (Berry, 2004), chiefs in Northern Ghana sit on symbolic hides which are equivalent to stools in the South. The 1992 constitution extended chiefly authority over land in the North, where previously it has been held by the state (Berry, 2004; Ubink and Quan, 2008).
} 
At the national level, where mining-forestry debates are focussed on formal large-scale mining in forest reserves, effective collaboration between agencies is facilitated through the mining in forest reserves liaison group. ${ }^{7}$ But coordination at a local level over informal and off-reserve mining issues is considerably weaker. Within forest reserves, the Forestry Commission is responsible for managing ASM activities which, without exception, are operating illegally. Outside forest reserves, it is theoretically the EPA which is responsible for addressing mining, but the prevailing view among policy makers is that doing so is beyond the scope and capacity of the EPA and that the Minerals Commission is de facto responsible for managing all mining activities, legal or otherwise. As a result, many miningforest conflicts fall between already stretched government agencies.

Furthermore, the lack of collaboration and co-ordination between agencies at the local level creates a discursive and governance gap which ASM falls through. As one district level government official from the Minerals Commission put it in an interview: 'As fieldmen, meetings between the Minerals Commission, Forestry Commission and EPA are haphazard and not institutionalised, so we only meet when we invite each other to workshops and things, but our big men interact'. Outlining temporal components of resource conflicts illustrates further the complexity involved in governing the mining-forestry nexus in Ghana. Of particular importance is the longevity of certain conflicts. In both the mining and forestry sectors, markets of concessions are historically linked with the colonial enterprise (Silver, 1981; Grove, 1997). The arrival of European mining companies precipitated a chaotic and disorderly market in concessions. The adverse effects of this period of contestation over land and resources still resonate in contemporary debates on resource management. The concession covering the resource conflict-riddled town of Obuasi, for example, was first instituted in 1897 (Ayensu, 1997). Discontent surrounding the Obuasi concession heightened local concerns regarding the impact of mining on the forests. One District Assembly member from a village near Obuasi reflected critically on this during an interview:

We lost some of our youth in 1994 when they confronted security guards. That was when the conflict was at its peak. Things have got better since then. The company have given us electricity for free, but we don't see it that way. We are paying a cost

\footnotetext{
${ }^{7}$ The cross-sectoral liaison group instituted under the 2001, 'Environmental guidelines for mining in production forest reserves in Ghana' facilitates coordination between different government agencies interested in mining in forest reserves, including the Water Resources Commission, Ghana EPA, Forest Services Division, Ghana Chamber of Mines and inspectorate division of the Minerals Commission.
} 
for the social and environmental damage caused by the mining. Forests and ecosystems have been destroyed... we used to have fish for free, now we have electricity for free.

It is important to appreciate the historical context of conflict dynamics to appropriately situate the roles and positions of key stakeholders. The subsequent discussion expands the argument further by examining the institutions and dynamics involved in cross-sectoral resource governance, first at the national, and second at local levels.

\subsection{National level cross-sectoral governance: The predominance of structural determinants}

Within the bounds of discussions on formal mining within forest reserves, state agencies demonstrate co-operation and coordination. But as the case of bauxite mining in Ghana outlined below demonstrates, the governance of the broader mining-forestry issues lack overarching frameworks to guide development which, in contrast to the ostensibly technocratic basis of decision making, leads to a politicisation of cross-sectoral governance.

Although the cross-sectoral liaison group facilitates coordination between different government agencies interested in mining in forest reserves, there are still concerns about the effectiveness of cross-sectoral integration in the broader governance landscape. One nongovernmental organisation (NGO) officer, for example, voiced concerns about the effectiveness of the national planning committee during an interview:

There are two different ministries, two different agencies, there's always friction of conflicting policies, so there's no overarching institution that is seeking to bring some synergy, or coordination... Probably you could say it's the national development planning commission, but they (don't) have the resources or the technical capacity to do such a distinction. It's mostly always political; the decision making process is almost always political.

A regional forestry manager raised similar concerns when reflecting on the prospect of bauxite mining in the Atewa Forest ${ }^{8}$ Reserve. The manager explained that 'it would be better if there were some national policy guidelines, but there are no standard guidelines, so that one is above us, it will go to cabinet'.

\footnotetext{
${ }^{8}$ Which has been designated an area of Globally Significant Biodiversity (GSB).
} 
The contention that cross-sectoral policymaking is politically-driven warrants further scrutiny because, as will be argued, it contrasts with the predominantly technocratic mode of governance widely espoused by government officials and donors. Despite raising crosssectoral issues as a concern, very little guidance is given through the Natural Resources and Environmental Governance (NREG) program on the governance of arising conflicts and that which is given is rooted in cost-benefit analysis (CBA). As the first program document under NREG states (World Bank, 2008:36), 'An independent, participatory cost-benefit analysis of the mining sector in all of its aspects (e.g., land degradation, environmental and social impacts) will be undertaken to determine whether, on balance, mining is beneficial to Ghana as a way to address public concern over this issue'. Although CBA is the primary tool for national cross-sectoral governance, it does not accurately describe the processes which actually govern national level cross-sectoral decision making. Rather, the focus on CBA is symptomatic of a policy discourse which is framed by the hegemonic neoliberal discourse, particularly the market-led paradigm of contemporary environmental governance (Humphreys, 2009). The case of the proposed mining of bauxite in the Atewa Forest Reserve is illustrative of this.

An integrated aluminium industry was a part of Kwame Nkrumah's early post-independent socialist vision for industrialisation (Tsikata, 1997). Even though the principal aspects of an integrated industry were developed, this has never fully been realised. The smelter built at Tema Harbour has consistently struggled to operate due to fluctuations in power prices and availability from the hydroelectric dam at the Volta; it invariably operates below 20 per cent capacity (Coakely, 2003). The smelter was originally majority owned by the Kaiser Aluminum \& Chemical Corporation (Kaiser) of the United States, but in 2003 Kaiser signed a memorandum of understanding to transfer its whole stake, liability and obligations to the state. ${ }^{9}$ The Ghana Bauxite Company, owned by the Chinese firm, Bosai Minerals, manages the country's only operational bauxite mine at Awaso. Productivity at the mine has been, and continues to be, constrained by lack of capacity of the railway to transport ore to the coast for shipping (Coakely, 2003).

One official from the Minerals Commission explained in an interview that despite the difficulties Ghana has had developing its bauxite industry, its association with Nkrumah's political vision and potential economic benefits means that: '...successive governments in this

\footnotetext{
${ }^{9}$ After which it was shut until 2011 (VALCO, 2013).
} 
country have been trumpeting that they want the country go into an integrated BauxiteAluminium industry'. That objective was given a boost in 2010 when Bosai Minerals signed a memorandum of understanding with the government, agreeing to invest US\$1.2 billion in developing the industry and a modern alumina refinery. Furthermore, the government has granted licences to carrying out prospecting within the Atewa Forest Reserve, an exception to a policy which prohibits mining in forest reserves. As one government official explained in an interview:

Quite recently [2011] Vimetco Bauxite Company was granted a prospecting licence to carry out exploration in a forest area. There are about two areas, but the prospecting licence are many, there are about five or so. The decision was made to allow Vimetco to go and carry out exploration because, since early 1920 or so, exploration was carried out. ${ }^{10}$

Although there is little transparency regarding this decision, the company was keen to maintain the impression of technocratic policy making based on cost-benefit analysis. When a project manager was asked in an interview whether the company's executive was confident of being allowed to progress to the exploitation stage, he explained that:

It is a political decision, the politicians have to decide - they can either mine the area, and it will provide so many jobs, or they can leave it as a forest, and nothing will come of it... there should be a cost-benefit analysis, and that will inform the political decision [emphasis added].

The decision regarding mining in Atewa will reputedly be made on a rational economic basis. However, this narrative epitomises how structural determinants of power and governance influence national and international decision making. In this case, decision making is being driven by historical precedent on the one hand, and on the other hand, by the hegemonic neoliberal discourse. These factors combined frame governance within a market based paradigm and pre-empt the factors of relevance in decision making which supersede alternative stances on cross-sectoral issues, particularly non-market environmental factors. Although there are several conservation NGOs attempting to change policymakers' frame of reference, they cannot compete with the power that multinational companies have over public

\footnotetext{
${ }^{10}$ Bauxite was first observed in the Atewa Range by Sir Albert Kitson in 1914 and was first prospected by the British Aluminium Company in 1957 (Kesse, 1974).
} 
discourse. Mining companies, as evidenced by their continued expansion in Ghana and elsewhere, have aligned themselves with global hegemonic discourses and are dominating discursive debates on cross-sectoral natural resource governance. But as the widespread presence of resource conflicts (e.g. Hilson and Yakovleva, 2007; Murguía and Böhling, 2013) demonstrates, companies have found it increasingly difficult to translate that success into operations which do not exacerbate local disputes over resources.

Mining companies become embroiled in local-level conflicts which are not so easily understood or controlled discursively. Effectively, cross-sectoral governance dynamics in the mining industry are transformed from structural discourses over trade-offs at the national level to conflicts over resource-use at the local level characterised by a wide variety of stakeholders demonstrating appreciable agency. In an attempt to alleviate the negative consequences of localised conflicts, companies and state institutions have adopted a technocratic rhetoric around participatory deliberative governance, and have employed consultants to try and accommodate local concerns within the vagaries of neoliberal discourse and transnational capital. An official from the Minerals Commission explained in an interview how additional royalties levied on companies mining in forested areas facilitated the employment of a consultant to integrate community concerns:

...a consultant goes there independently to carry out a needs assessment, and then the consultant will spell out what has to be done for the various communities based on the information gathered from the field... this is being done to ensure there is equity and fairness.

The use of consultants, or 'development experts', to govern conflicts arising from crosssectoral interactions is one component within a broad matrix of stakeholders which has appreciable agency over governance at the local level. The following section reviews this matrix, arguing that it interacts sporadically with a series of disconnected government agencies which, unintentionally, support the proliferation of informality and corruption.

\subsection{Local cross-sectoral governance: Untangling stakeholder agency}

As previously detailed, local government agencies responsible for managing the intersection of mining and forestry are characterised by institutional fragmentation. The clear and concrete delineation of responsibility between agencies combined with a lack of collaboration 
at the local level inhibits the successful monitoring and enforcement of laws governing forest conservation and mining, especially in the small-scale sector. The resultant high levels of informality render cross-sectoral governance arrangements a complex matrix composed of a variety of stakeholders, notably traditional authorities, land owners and financiers. Although structural components are also relevant to developing an understanding of local governance, this section of the paper argues that stakeholders demonstrate relatively more agency over decisions regarding ASM in forested areas than those governing at a national level who are confined within neoliberal discourses and policy path dependencies.

Traditional authorities are central to the governance of ASM in forested areas, and wider resource management dynamics, because they are the customary land holders (Nyame and Blocher, 2010). Much of their involvement can be traced to dissatisfaction regarding the distribution of benefits accruing from resource use, especially minerals which are vested in the state. While they receive mineral royalties from operations in the large-scale sector, chiefs receive minimal direct benefits from gold mined in the formal ASM sector. Similarly, although traditional authorities relinquished primary responsibility for much of Ghana's forest stock through the colonial imposition of forest reserves, residual discontent combined with a lack of tangible benefits accruing to them from forest reserves means that in some areas, they want to renegotiate the terms of forest reserves, or simply, do not support state efforts to protect them. One forest reserve manager indicated that some chiefs in his jurisdiction wanted to renegotiate the boundary of the reserve because more benefits might be realised for the community.

Although this is not a forest management strategy under serious consideration, it is often a de facto occurrence as, according to some chiefs, local forest managers agree informally to allow access to reserves for farming and mining. None of the reserve managers interviewed explicitly indicated that they had entered into such informal agreements, but some did highlight how the relatively large sums of money involved in illegal ASM, the personal risk to their safety ${ }^{11}$ and the perceived futility of arresting miners ${ }^{12}$ combined to incentivise corrupt practices. The agency of chiefs and forest reserve managers, however, is evidenced by the spatially heterogeneous distribution of ASM among forest reserves; where chiefs and

\footnotetext{
${ }^{11}$ Several forest guards have been killed by small-scale mine operators in recent years (Ghana Broadcasting Corporation, 2013).

${ }^{12}$ Because 200 cedi ( 100 USD) court fines are an inadequate deterrent.
} 
reserve managers present a united position against small scale miners in forest reserves, such as in Atewa, ASM activities are restricted.

The contention over the benefits related to resource-use and subsequent precipitation of informal agreements between chiefs and local state managers is exacerbated by a lack of knowledge among some chiefs regarding the mining industry and associated laws. One Minerals Commission officer explained in an interview how, in light of widespread misconceptions about the process for gaining concessions, education is the key to resolving disputes:

'Some chiefs came here, saying we won't agree, we won't agree. I sat them down here, and then I educated them... they went to Accra and my boss said, he has told you the true facts... and now the case is resolved. They've gone back to what I told them to do, and they are now happy. They've even gone to bring the applications, for me to process for them.'

This illustrates how the collaborative behaviour of key stakeholders exercising their agency can lead to improved governance outcomes. There are, of course, structural issues which limit the capacity of such relationships developing. The lack of geological data, for example, is compounded by discrepancies between maps held at the Minerals Commission and Forestry Commission. Examining the power dynamics between key stakeholders sheds further light on both the inadequacy of sectoral and technocratic approaches to resource governance and the deeply political nature of the context within which mining-forest debates are embedded.

\section{Critical reflections on stakeholder power, authority and legitimacy}

The dual concerns of environmental protection, particularly climate change, and economic well-being are at the heart of endeavours to understand the governance of natural resources. The process and outcomes of decision making around mining and forests, particularly where they overlap spatially, are dependent on the power, legitimacy and authority of key stakeholders. The analysis that follows reviews the power relations between the three principal stakeholder groups associated with the governance of the mining-forest nexus: mining companies, traditional authorities and the state. The discussion highlights how variable and perspective dependent legitimacy can be among stakeholders. Traditional authorities, for example, have considerable popular legitimacy in the ASM sector which is 
not reflected in the large-scale sector. It is argued that the postcolonial state has failed to accommodate these dynamics which, combined with subservience to donor interests, has led to an erosion of its authority over resource management.

\section{1 'Can you battle Gold Fields?': Power and legitimacy in the mining sector}

Several of the mining companies operating in Ghana's forest reserves are large multinational entities whose power is rooted in their considerable economic capital. Companies have leveraged this power to establish and maintain control over Ghana's premium ore deposits, including those in forest reserves. The lack of transparency regarding decisions to allow mining companies to operate in forest reserves gives rise to concerns that mining companies have also used their economic power to lubricate their entry into reserves through corrupt means.

Suspicions of high-level bribery and corruption in the mining industry are notoriously difficult to substantiate, but mining companies also use their economic power to control and influence public discourse and subvert dissenting voices. Mining companies have perpetuated the development discourse, which posits minerals as the foundation of economic growth, and outline the threat that undermining their operations equates to lessening the economic benefits associated with mining. In Ghana, one mining company was lauded for holding journalist training (Daily guide, 2011). While a proactive and critical media can usefully hold multinational companies to account, the objectivity of journalists trained by mining companies is questionable and this dominance potentially subverts opportunities for a well informed and balanced public discussion.

An NGO officer explained further in an interview how mining companies' economic wealth translated into power over public discussion. The officer argued that a lack of environmental lawyers in the country, coupled with a judiciary with a poor ecological understanding, undermined attempts to tackle mining companies through the law courts. Although: 
...some lawyers in Accra are working [on environmental issues] on a no win, no fee basis... NGOs don't have the expertise or capacity to support communities who know they are being wronged... how can you battle Gold Fields ? $^{13}$

In the ASM sector, money is also a key component of power dynamics, but it manifests differently. Unlike the large-scale sector, there is a considerable degree of heterogeneity regarding the economic power of actors in the small-scale sectors. In general, it is the sponsors, gold buyers and land owners, in partnership with the chiefs, who are profiting from the sector and accordingly have power over where and when ASM occurs. One land owner and sponsor in the Eastern Region touched on this power during an interview:

We don't allow them [the miners] to enter the forest reserve, those people in the reserve are hunters... and the chief is campaigning for the environment. So, he won't allow people to go into the reserve.

Other participants in the sector have considerably less influence over where mining occurs. For some of these actors, it is the promise of wealth that incentivises their entry into the sector. In reality, many poverty-driven entrants into ASM stay poor and remain trapped in the sector (Hilson, 2012). They are effectively subject to their sponsors and have little control over their activities. One miner typified his position during an interview when he said, 'we're just the workers... we are working to chop [eat].'

The public political discussion on ASM in Ghana, however, fails to address the heterogeneity within the sector, even though it is well known. One sponsor explained how his application for a concession was rejected on the basis that someone else who was 'higher up in the party' got precedence. The involvement of public officials in the sector suggests that some powerful members of Ghanaian society may be framing small-scale miners as scapegoats to deflect attention away from the actors who are actually responsible for the proliferation of mining activities.

The influx of Chinese migrants who are willing to sponsor activities further complicates the political dynamics (Hilson et al., 2014). On one hand, they are welcomed as a source of investment and operate within the matrix of sponsors, land owners and chiefs, but on the other they are grouped together with small-scale miners and presented as an uncontrollable threat. The latter position reflects the treatment of some miners as scapegoats, because, while

\footnotetext{
${ }^{13}$ Goldfields is a large-scale gold mining company operating the Western Region.
} 
some Chinese may be working independently, in most instances their operations would not be viable without the acquiescence of the local chiefs and security forces. The presence of conflicts around mining areas, in both the large- and small-scale mining sectors, betrays a lack of local legitimacy among key stakeholders. In the mining sector, chiefs are influential stakeholders and understanding the landscape of their authority is an essential component of understanding cross-sectoral governance and resource-use conflicts in Ghana.

\subsection{Lumpy legitimacy: How powerful are traditional authorities in natural resource governance?}

The British colonial policy of indirect rule both increased the power chiefs had over resources and simultaneously undermined their sovereignty and accountability by placing their authority under that of the governor (Addo-Fening, 2008). In contemporary resource governance, chiefs remain a primary stakeholder. In the large-scale mining sector, it is predominantly paramount chiefs who hold power over development outcomes through the receipt of royalties and who are considered legitimate representatives of communities by mining companies. But this power is often unrealised, leading to division in communities and a lack of local legitimacy. In the ASM sector, chiefs across the hierarchical structure have considerable authority but sometimes operate in direct conflict with state and with little accountability. The consequential 'lumpy' legitimacy of chieftaincy characterises much of the complexity typical of contemporary debates regarding the role of the state and traditional authorities in resource governance.

The granting of large-scale mining concessions is contingent on the approval of both local and paramount chiefs. But in practice, the constitutional vesting of minerals in the state renders traditional authorities' role in decision making passive and increasingly ceremonial. Chiefs do, however, have considerable power over the development outcomes of mining activities through the receipt of royalties. This power is largely latent though as disagreements between stools regarding land ownership often delay the distribution of royalties. This is currently the case around Obuasi, where seven stools under the Adansi Kingdom are amicably trying to resolve a dispute over land. ${ }^{14}$

\footnotetext{
${ }^{14}$ Information from an interview with a Chief (16.05.12)
} 
The power of chiefs over development outcomes in large-scale mining communities can also be considered as mostly unrealised because benefits are rarely widely distributed, which can lead to poor relationships within mining communities. The case of Dokyiwa in Obuasi Municipality is illustrative. In this case, the village chief (odikro) was given money and a job as part of the settlement package for the re-location of the village even though, as villagers complained repeatedly during an interview, 'he is illiterate'. From the perspective of the mining companies, chiefs are legitimate representatives of communities and conduits for benefit sharing. The lack of benefit sharing within mining communities, however, means that despite their formal authority over land they lack local legitimacy. The lack of popular acceptance of their authority exacerbates conflicts as aggrieved communities pursue their livelihoods by, for example, accessing non-timber forest products (NTFPs) or ASM areas on mineral concessions without regard for formal agreements between mines and chiefs. Substantive opposition to chiefs, however, is rarely manifested due to a lack of accountability mechanisms ${ }^{15}$ and their deeply-rooted cultural authority (Yankah, 2008). As one district assembly member in a mining area explained in an interview: 'In these communities, if you want to get up and make a noise, or try and hold people accountable, your own parents will tell you to sit down'.

With regard to the large-scale mining sector, chiefs at all levels, have legitimacy from the perspective of mining companies and formal state mechanisms, but have less legitimacy among their communities. In the ASM sector, the character of chiefs' legitimacy is effectively reversed. Among communities they have higher levels of legitimacy supported, in most cases, by their role in developing the activity. One miner explained in an interview how popular the chief was because he negotiated an agreement with the Forestry Commission over an area where they could mine undisturbed and had also organised the collecting of rubbish in the village.

The illegality of the majority of ASM activities, however, undermines their broader legitimacy from the perspective of the state. The view of one Forestry Commission officer, articulated during an interview, reveals both how important the chiefs are in the sector, and how their role is negatively perceived by state agencies:

\footnotetext{
${ }^{15}$ The Asafo (a group of men from the wider population who come together to 'restrain the chief from acting in complete disregard to the popular will') used to represent an accountability mechanism for chiefs, but this tradition appears to have disintegrated over the last century (Addo-Fening, 2008:37).
} 
By tradition, mining, or any other activity on the chiefs land, cannot happen without the chiefs consent. However, it happens sometimes that some of the chiefs are conniving or colluding with the illegal miners. In the formal ASM sector the benefits get shared out, so some chiefs prefer to work without a permit in order to take all the royalties, and not divide them.

The view of a district planning officer, divulged during an interview, further supports the contention that state officials perceive chiefs to be powerful actors in the ASM sector. Discussing the scope for communities to control ASM in their area, he said:

People might agitate, but to what effect, what power do they have? Some have succeeded with the help and power of chiefs, but without the chief, they don't have any power.

Although this characterisation of chiefly power in the ASM sector captures the majority of contexts, some chiefs promote a different discourse. Some chiefs argued that they lack any power over miners, even in some cases on their own farms. This not only highlights the heterogeneity of the sectors dynamics, but also alludes to how actors are using the ASM sector to position themselves within broader development and governance debates.

Denney (2013) moots the question of whether donors should consider chiefs, whose governance mode contrasts with the participatory democracy ideology of the donors, as legitimate partners and notes the considerable challenge with co-opting them into predominantly state-led interventions. These debates do not question the cultural and historical authority of traditional authorities. In fact, as Ubink and Quan (2008) suggest, the state policy of non-interference with 'chieftaincy issues' ${ }^{16}$ is so pervasive that it prevents an accurate and open articulation of land-based issues in Ghana. By aligning themselves with national discourses on the uncontrollable nature of ASM and the necessity for environmental protection, ${ }^{17}$ some chiefs can be seen as pursuing a legitimising strategy and attempting to position themselves for an increasingly influential role in Ghana's resource management.

This contention requires that some consideration is given to the potential involvement of chiefs in emerging forestry projects such as REDD+ and development strategies more

\footnotetext{
${ }^{16}$ The term 'chieftaincy issues' is widely used to refer to issues regarding land ownership and chiefly jurisdiction.

${ }^{17}$ For example, the Okyenhene established an environmental task force in the Kibi area and has also founded the Okyeman Environment Foundation, which has received funding from the World Bank's Global Environment Facility (Roosbroeck, 2006)
} 
generally. Their involvement in projects is likely to be imperative if projects are to garner the popular support and access to land required. Moreover, their role in the distribution of benefits requires explicit attention. If carbon projects reflect institutional arrangements in the mining sector, then chiefs would benefit directly through the payment of royalties. If these funds are used appropriately then projects could benefit from the popular legitimacy chiefs enjoy in some areas. Conversely, if, as is sometimes the case in large-scale mining communities, royalties are not used for the wider benefit of communities then REDD+ projects could face serious difficulties in ensuring equity within projects and also wider legitimacy, which in turn could lead to the disruption of arrangements to conserve or enhance forest stocks. There are not easy technical solutions to these problems; they are political issues. For example, if projects agree, as some large-scale mines have, to pay some proportion of the financial benefits as royalties to chiefs and distribute other funds directly to other members of communities, then that arrangement implicitly legitimises the view that royalties are distributed to traditional authorities rather than through traditional authorities.

Traditional authorities are evidently central to power dynamics in Ghana's natural resource sectors, but their power and legitimacy varies greatly depending on the sector and their corollary relationship with companies, communities and state agencies. The hierarchical structure of traditional authorities, including paramount chiefs (omanhene), divisional chiefs (ohene), and village chiefs (odikro), also shapes their influence role in resource governance. Investigating in greater detail the role of traditional authorities across the hierarchy in mineral and forest governance would provide more nuanced understandings of governance dynamics and should be considered essential knowledge to incorporate into development interventions targeted at mining or forestry sectors. But in general, chiefly power in the large-scale sector is largely latent. And, in the ASM sector, a minority of chiefs appear to be positioning themselves to seek greater recognition in state centric resource management regimes.

\subsection{Authority without legitimacy: Undermined state power in natural resources sectors}

In Ghana, the state has considerable authority to influence natural resource management and interventions in the sector tend to be exclusively state centric. This section argues, however, that state power is limited by the implementation of policies which do not account for the importance of 'informal' activities such as ASM and chainsawing in communities' livelihoods. This both undermines the legitimacy of state policies, but also induces conflicts 
between state agencies and security forces on the one hand, and resource users on the other, which further inhibit the influence of local government agents.

Since the 1992 constitution was ratified by more than 90 per cent of the population in a referendum, Ghana has enjoyed a period of relative stability characterised by strengthening democracy and generally high levels of legitimacy (Gilley, 2012). ${ }^{18}$ While there is popular acceptance of the state and democracy at a national level, conflicts over resources at a local level suggest that its constitutional authority to legislate over natural resources lacks legitimacy. The lack of popular acceptance, at a local level, of resource-use laws results from policymakers neglecting to consider both the dynamics of sectors and the importance of activities, such as ASM or chainsawing, in the lives of those who engage in the activities.

In the case of ASM, formalisation has failed to account for the characteristics of most participants (Teschner, 2012); even miners who would like to gain the security of a formal small-scale licence complain that it is prohibitively expensive and time consuming. Furthermore, the lack of geological data in the country means there is no guarantee that there will be any gold in the concession. One miner summarised the issue succinctly in an interview: 'it is either a waste of time, or money, or both'. The 1998 blanket ban on chainsaw lumber led to even greater levels of 'informality' in the chainsaw sector than in the ASM sector where only 10 per cent of activities operate legally.

The widespread criminalisation of important livelihood activities has been met with local resistance, manifest simply in the continued pursuit of activities. This is symptomatic of the lack of legitimacy among state actors charged with managing natural resources. It has also led to a very narrow one-dimensional approach to the conflicts. Where state agencies have attempted to enforce resource management laws, they have engaged in largely futile and protracted conflicts channelled through the military and police forces. These interventions are often ineffective or temporary as it is logistically and financially challenging to maintain a widespread 24-hour security presence over large areas.

In response to the logistical challenges associated with coordinating security forces, the Forestry Commission has instituted an armed rapid response unit to help guard forest reserves. However, it is not only the lack of capacity to enforce laws through force which

\footnotetext{
${ }^{18}$ This is supported by the 2012 Afrobarometer survey which found that 82 per cent of Ghanaians prefer democracy over non-democratic governance and 74 per cent of Ghanaians are fairly or very satisfied with the way democracy works in Ghana (Afrobarometer, 2012).
} 
limits state power over resources. In ASM, for example, once operators reach court, there is insufficient scope within the law for judges to account for the heterogeneity of miners. Forestry Commission officials interviewed complained that relatively small (200 cedis) ${ }^{19}$ fines in the courts represent an ineffective deterrent to sponsors and financiers.

The inconsequential nature of punishments meted out by the judiciary towards ASM serves to demotivate officials and incentivise corruption. There is no incentive for forestry officials to risk arresting miners in forest reserves when they will return after a short period.

Furthermore, the political climate around natural resources in Ghana, particularly ASM, means that government officials are reluctant to visit illegal sites to engage miners with advice on the formalisation process or where to mine ${ }^{20}$ because they will be labelled as corrupt. Furthermore, because of the militarised nature of conflicts they avoid illegal sites because they 'don't know what weapons they might have.' 21

These dynamics restrict local and district level state actors to the formal channels. And hence limit their influence over the majority of resource use contexts. At the national level, power over natural resource governance is threatened by broader trends regarding diminishing national sovereignty (Whitfield, 2009; Abdulai and Crawford, 2010; Brown, 2013). An illustrative example of this was highlighted by an EPA official, when he mused on the adoption of the REDD+ programme in the country at the behest of donors after a decision had been taken to shift away from program based support to general budgetary support. This shift was typified by the development of the NREG program, which was implemented in response to criticisms that donor assistance in the natural resource sector was poorly coordinated. The near-total omission of chiefs from the NREG policy program demonstrates how, through a reluctance to engage substantively with the influence of traditional authorities in resource governance, donors have eroded the ability of the state to approach, and potentially resolve these issues.

Well-articulated concerns regarding the sovereignty of the state in postcolonial Ghana are being augmented by the introduction of Chinese development assistance (Tull, 2006; Mohan and Power, 2008). The recently agreed US\$3bn development assistance from the China

\footnotetext{
${ }^{19}$ About 60 US dollars.

${ }^{20}$ The lack of geological information is exacerbated by a lack of knowledge among miners who are criticised for speculative mining in unsuitable areas further worsening environmental degradation. One officer from the Minerals Commission says he can advise miners on the basis of his geological knowledge and they will consider him the 'best magician'.

${ }^{21}$ Interview with forestry official (01.06.12)
} 
Development Bank has been linked with the influx of Chinese operators in the ASM sector and the relative impunity with which they appear to operate. The anecdotal rise in conflicts involving Chinese operators appears to lend credence to these concerns (Nossiter and Feng, 2013), but substantiating these concerns is extremely challenging.

In summary, while the state has considerable authority to manage natural resources, this is undermined in two principal ways. First, by a lack of legitimacy at a local level rooted in poorly formulated policies which marginalise resource users who are heavily dependent on natural resource for their livelihoods; and second, by the erosion of sovereignty over resources engendered by the influence of foreign donors over policy.

\section{Concluding remarks}

Against mounting concern regarding the deleterious environmental and social impacts of poorly managed mining economies in sub-Saharan Africa, this paper has explored the governance of mining and forest activities in Ghana's high forest zone. By examining interaction between sectors across scales, it was demonstrated that at a national level, relatively co-operative relations between agencies give the impression that resolving conflicts and divergent sectoral priorities is a technical matter of negotiating trade-offs. But locally, resource managers are faced with more tangible conflicts which are exacerbated by poor sectoral coordination, but are potentially more amenable to individuals and groups exercising their agency.

These dynamics are reflected in involvement of mining companies who use their economic power to orientate national discourse around the costs and benefits of activities and associated impacts on economic growth, as well as find themselves embroiled in local conflicts which unmask the political dimensions of natural resource conflicts. The complexity of governance arrangements is typified by the contestations over, and vagaries of, the legitimacy and authority of traditional authorities in mine and forest activities. In the largescale mining sector, although the role of chiefs is generally passive, their power to influence development outcomes through the distribution of royalties is largely latent, undermining their legitimacy in communities. In the ASM sector, however, it is their legitimacy in the eyes of the state which is diminished due to their role in perpetuating the activity which is widely considered to be environmentally and socially damaging despite providing livelihoods for more than a million individuals. 
The 'lumpy' legitimacy of traditional leaders is reflected in the authority of the state which, this paper has argued, has been eroded by diminishing local legitimacy as swathes of the country's citizens have failed to realise sufficient benefits from the exploitation of mineral and forest resources. The state centric nature of emerging natural resource management initiatives means this contention is of critical importance. Although countries across subSaharan Africa vary greatly in their specific governance arrangements, the case of Ghana illustrates that, in general, if policies and projects continue to neglect the reality of power dynamics between key stakeholders and resource governance continues to be understood primarily as a technocratic cost-benefit exercise, the prospects for donor-led interventions in the natural resources sector remain bleak.

The mining-forestry issues outlined in this paper are embedded in much broader debates regarding the role of the state, traditional authorities and civil society and the market. As it is impossible to take a politically-neutral position on these issues, this paper advocates for more space to be created for these sensitive but vital questions to be deliberated among politicians, policymakers, academics and civil society more generally. Development donors could do considerably more to assist this process, most notably by having in place a more coherent and comprehensive strategy for integrating traditional authorities into their projects and perhaps by creating a forum for discussions to take place. Ultimately, however, this should be addressed by Ghanaians because as several decades of experience of ideologically-driven interventions suggest, externally imposed ideas of 'good governance' are unlikely to deliver the outcomes they aim for, however well-intentioned they may be.

\section{Acknowledgements}

The author wishes to thank Prof. Gavin Hilson and Prof. Mark Hodson for their support and encouragement, Atta for this assistance during the fieldwork, all the participants who generously shared their time and experience and two anonymous reviewers whose comments helped improve the paper. This research was funded by an ESRC-NERC interdisciplinary PhD studentship. 


\section{References}

Addo-Fening, R. (2008) 'The Relevance of 6Traditional Governance' in: B. Agyeman-Duah (ed) Ghana - Governance in the Fourth Republic, pp.32-56. The Ghana centre of Democratic Development, Tema, Ghana: Digibooks,.

Akabzaa, T. (2000). Boom and Dislocation: Environmental and Social Impacts of Mining in the Wassa West District of Ghana. Accra, Ghana: Third World Network.

Ayensu, E. (1997) Ashanti Gold - The African Legacy f the World's Most Precious Metal. London: Ashanti Goldfields Company Ltd, Marshall Edition.

Berry, S (2004) Reinventing the Local? Privatization, Decentralization and The Politics Of Resource Management: Examples from Africa, African Study Monographs 25(2): 79-101.

Brown, W. (2013) Sovereignty Matters: Africa, Donors and the Aid Relationship, African Affairs 112(447): 262-282.

Coakley, G. (2003) The Mineral Industry of Ghana. USA: US Geological Survey Minerals Yearbook - 2003.

Colfer, C.J.P. (2011) Marginalized Forest Peoples' Perceptions of the Legitimacy of Governance: An Exploration, World Development 39: 2147-2164.

Cotula, L. (2012) The international political economy of the global land rush: A critical appraisal of trends, scale, geography and drivers, The Journal of Peasant Studies 39: 649680 .

Cotula, L. and Mayers, J. (2009) Tenure in REDD—Start-Point or After-thought? London: International Institute for Environment and Development.

Daily guide. (2011). Newmont Backs Quarterly Training Of Financial Journalists. Modern Ghana. URL: http://www.modernghana.com/news/333123/1/newmont-backs-quarterlytraining-of-finan.html [29.4.05]

Denney, L. (2013) Liberal Chiefs or Illiberal Development? The Challenge of Engaging Chiefs in DFID's Security Sector Reform Programme in Sierra Leone, Development Policy Review 31: 5-25.

Dominguez, G. and Plana, E. (2002) 'The status of intersectoral coordination in SFM in Catalonia - lessons learnt from an experimental qualitative research design', in: I. Tikkanen, P. Glueck, and H. Pajuoja, (eds) Cross-Sectoral Policy Impacts on Forests, EFI Proceedings, vol. 46. Joensuu: European Forest Institute.

Dondeyne, A., Ndunguru, E., Rafael, P. and Bannerman, J. (2009). Artisanal mining in central Mozambique: Policy and environmental issues of concern. Resources Policy. 34 (1-2), 45-50.

Edwards D., Sloan, S., Weng, L., Dirks, P., Sayer, J. and Laurence, W. (2013) Mining and the African Environment Conservation Letters 7: 302-311.

Ferguson, J. (2006). Global Shadows - Africa in the Neoliberal World Order. Durham, London: Duke University Press. 
Foucault, M. (1994) Power, The New Press, New York.

Giddens, A. (1984) The constitution of society. Outline of the Theory of Structuration. Cambridge: Polity Press.

Gilley, B. (2012) State Legitimacy: An updated dataset for 52 countries, European Journal of Political Research 51: 693-699.

Grimble, R. and Wellard, K. (1997) Stakeholder Methodologies in Natural Resource Management: a Review of Principles, Contexts, Experiences and Opportunities, Agricultural Systems 55: 173-193.

Grove, R. (1997). Ecology, climate and empire: colonialism and global environmental history, 1400-1940. Cambridge: White Horse.

Gupta, J. (2012) Glocal forest and REDD+ governance: win-win or lose-lose? Current Opinion in Environmental Sustainability, 4: 620-627.

Hellström, E. (2001) Conflict Cultures - Qualitative Comparative Analysis of Environmental Conflicts in Forestry. Finland: The Finnish Society of Forest Science.

Hilson G. (2012) Poverty Traps in Small-Scale Mining Communities: The Case of SubSaharan Africa Canadian Journal of Development Studies, 33(2): 180-197.

Hilson, G., Hilson, A. and Adu-Darko, E. (2014) Chinese participation in Ghana's informal gold mining economy: Drivers, implications and clarifications, Journal of Rural Studies 34: 292-303.

Hilson, G. and Nyame, F. (2006) Gold mining in Ghana's forest reserves: a report on the current debate Area 38 (2): 175-185.

Hilson, G. and Yakovleva, N. (2007). Strained relations: A critical analysis of the mining conflict in Prestea, Ghana, Political Geography 26: 98-119.

Hirons, M. (2013). Mining in Ghana's forests: cross-sectoral linkages and the prospects for RDD. International Planning Review 35 (3), 283-300.

Hirons, M., Hilson, G., Asase, A. and Hodson, M.E. (2014). Mining in a Changing Climate: what scope for forest-based legacies? Journal of Cleaner Production. In press: DOI: 10.1016/j.jclepro.2013.11.025

Humphreys, D. (2009) Discourse as ideology: Neoliberalism and the limits of international forest policy, Forest Policy and Economics 11: 319-325.

Kesse, G.O. (1974) Bauxite Deposits of Ghana. Ghana Geological Survey Report 75/2. Accra: Republic of Ghana.

McLaughlin, P. and Dietz, T. (2008) Structure, agency and environment: toward an integrated perspective on vulnerability, Global Environment Change. 18: 99-111.

Mohan, G. and Power, M. (2008) New African Choices? The Politics of Chinese Engagement, Review of African Political Economy 35(115): 23-42. 
Murguía, D. and Böhling, K. (2013) Sustainability reporting on large-scale mining conflicts: the case of Bajo de la Alumbrera, Argentina, Journal of Cleaner Production 41: 202-209.

Mwitwa, J., German, L., Muimba-Kankolongo, A. and Puntodewo, A. (2012) Governance and sustainability challenges in landscapes shaped by mining: Mining-forestry linkages and impacts in the Copper Belt of Zambia and the DR Congo, Forest Policy and Economics 25: 19-30.

Nossiter, A. and Feng, B. (2013). Ghana Arrests Chinese in Gold Mines $-6^{\text {th }}$ June 2013. New York Times. URL: http://www.nytimes.com/2013/06/07/world/africa/ghana-arrests-chinesein-gold-mining-regions.html? $\mathrm{r}=0$ [29.4.15].

Nyame, F. and Blocher, J. (2010) Influence of land tenure practices on artisanal mining activity in Ghana, Resource Policy 35: 47-53.

Republic of Ghana. (2005) Growth and Poverty Reduction Strategy (GPRS II) (2006 - 2009). http://planipolis.iiep.unesco.org/upload/Ghana/PRSP/Ghana\%20PRSP\%20June\%202006.pdf (accessed 27 June 2014).

Roosbroeck, V.P. (2006). Country Environmental Profile of Ghana - draft final report prepared for the European Union.

http://ec.europa.eu/development/icenter/repository/Ghana\%20_CEP_2006.pdf (accessed 01 August 2013).

Sayer, J., Sunderland, T., Ghazoul J., Pfund, J., Sheil, D., Meijaard E., Ventera, M., Boedhihartono, A., Day, M., Garcia, C., van Oosten, C., Buck, L. (2013) Ten principles for a landscape approach to reconciling agriculture, conservation, and other competing land uses PNAS 110: 8345-8348.

Sewell, W. (1992) A Theory of Structure: Duality, Agency and Transformation. American Journal of Sociology, 98: 1-29.

Simmons, J. and Lovegrove, I. (2005) Bridging the conceptual divide: lessons from stakeholder analysis. Journal of Organisational Change Management, 18: 495-513.

Sikor, T. and Lund, C. (2009) Access and Property: A Question of Power and Authority. Development and Change, 40: 1-22.

Silver, J. (1981) The Failure of European Mining Companies in the Nineteenth-Century Gold Coast. The Journal of African History, 22: 511-529.

Teschner, B. (2012) Small-scale mining in Ghana: the government and the galamsey. Resources Policy, 37: 308-314.

Tsikata, F. (1997) The vicissitudes of mineral policy in Ghana, Resources Policy 23(1-2): 914.

Tull, D.M. (2006). China's engagement in Africa: scope, significance and consequences, The Journal of Modern African Studies 44(3): 459-479.

Ubink, J.M. and Quan, J.F. (2008) How to combine tradition and modernity? Regulating customary land management in Ghana, Land-use Policy 25: 198-213. 
VALCO (Volta Aluminium Company Ltd). (2013) History.

http://valco.solutionicons.com/about-us/history.html (accessed 30 June 2013).

Whitfield, L. (ed) (2009) The Politics of Aid - African Strategies for Dealing with Donors. Oxford: Oxford University Press.

Whitmore, A. (2006). The emperors new clothes: Sustainable mining? Journal of Cleaner Production. 14, 309-314.

World Bank. (2006) Ghana Country Environmental Analysis, Washington DC: World Bank.

World Bank. (2008) International Development Association Program Document For A Proposed Credit In The Amount Of Sdr 12.5 Million (Us\$20 Million Equivalent) To The Republic Of Ghana For A Natural Resources And Environmental Governance First Development Policy Operation (NREG DPO1). Report No. 42787 - GH. Washington DC: World Bank.

Yankah, K. (2008) 'Cultural Influences on Governance' in: B. Agyeman-Duah (ed) GhanaGovernance in the Fourth Republic, The Ghana centre of Democratic Development. Tema, Ghana: Digibooks.

Young, O., Underdal, A., Kanie, N., Andresen, S., Bernstein, E., Biermann, R., Gupta, J., Haas, P., Iguchi, M., Kok, M., Levy, M., Nilsson, M., Pintér, L. and Stevens, C. (2014) Earth System Challenges and a Multi-Layered Approach for the Sustainable Development Goals. POST2015/UNU-IAS Policy Brief \#1. Tokyo: United Nations University Institute for the Advanced Study of Sustainability. 